\title{
THE ROLES OF SOPHIE NEVEU AS REFLECTION OF WOMEN'S EQUALITY IN DAN BROWN'S THE DA VINCI CODE NOVEL
}

\author{
Rini Rahayu \\ Pepi Siti Paturohmah \\ Ujang Suyatman \\ State Islamic University of Sunan Gunung Djati Bandung
}

\begin{abstract}
This research analyzes women's issues in The Da Vinci Code novel by Dan Brown. In the novel there is a female character named Sophie Neveu. Sophie's role as a woman who can be relied upon in various situations makes her considered as woman who carries the spirit of feminism. The researchers decided to examine the role of Sophie Neveu as reflection of women's equality in The Da Vinci Code novel. The main theory used is Liberal Feminism by Betty Friedan. The form used in this research is qualitative and descriptive method in process of data analysis. The results of the discussion of this research are 1). Sophie Neveu play eleven roles of masculine qualities i.e. strong woman, competitive, courageous, unyielding, confident, independent, adventurous, aggressive, assertive, intelligent and generally acting as leaders, and; 2). The factors that make Sophie Neveu able to play this role is the background of her education. The conclusions of this research are masculine characteristics that can be owned by women and men, to become advanced individuals, women as part of the community must have equal opportunities as men in getting equal education, and the last that education is very important.
\end{abstract}

Keywords: Characterization, Women's issues, Women equality, Liberal feminism, Masculine qualities

\section{Introduction}

Fiction is an imaginary or unreal story. It can be in the form of a novel. The word "novel" comes from Italian language novella. The word novella literally means "a little new stuff", and then interpreted as "short story" (Abrams, 2009: 226). It sounds like a novel and short story are similar, but actually they are not. The theme, character and characterization, setting, and plot of a novel and short story are different. A novel can be said more complex than a short story. For example, if the short story usually only focuses on one character, the novel does not. Abrams explains that the short story focuses on the protagonist character and its plot primarily focuses on the course and outcome of the event (2009: 331).

Nurgiyantoro (2012: 23-24) writes that a novel as fiction has intrinsic and extrinsic elements. Intrinsic elements are elements that directly influence and construct the story of the novel. They are theme, plot, point of view, character, characterization, and setting. Here, the researcher focuses on intrinsic element that is character. Characters in a story or a novel are important because they move the plot inside it. There is at least one character as a focus in a novel. There are female or male characters or both in a novel. Female characters in a novel are considered to be an important topic to discuss because women seem oppressed by gender roles 
widespread in society.

Research about women issue was previously written by several researchers. First, research is entitled "Analysis on the Issue of Women Oppression in F. Scott Fitzgerald's The Great Gatsby" by Affroni and I.M. Hendrarti. They used a qualitative research method in analyzing the impact of patriarchy in the society depicted in The Great Gatsby movie and the form of women oppression in the movie. Feminism theory by Rosemarie Tong was used in their paper. The paper concluded that Daisy Buchanan and Myrtle Wilson represented the oppressed women in the patriarchal society. The similarity between those prior researches with this paper is discussing the same topic about women's issues whereas the differentiation is in the data or objects that are analyzed. This research is a new one that analyzes women's issues in Dan Brown's The Da Vinci Code novel.

Second research is "Analysis of Intrinsic Elements of Ito's Secret Meede Novel and The Da Vinci Code by Dan Brown: A Comparison" by Tuslianingsih, Faculty of Cultural Science, University of Indonesia 2010. This research discusses about intrinsic element analysis based on the point of view, plot, characters and themes. The theory used in this study is comparative literature in the analysis of intrinsic elements in which there is a point of view and focus on storytelling, flow and channeling, character and characterization, and themes. The other hand, the approach used is qualitative method using library research, and using descriptive analytical techniques. It can be concluded that Secret Meede's novel and Da Vinci Code novel have many similarities. In comparative literature, this is likely to occur because a particular work is influenced by another work. In a study conducted by Tuslianingsih he concluded that Meede's Secret novel was influenced by the Da Vinci Code novel.

The third, titles Grey's Struggle for Independence Life as Seen in Ann Bronte's Agnes Grey: A Feminist Study. It is written by Iramaya Nainggolan, a literary researcher from State University of Yogyakarta. Based on her research, women experience two problems; patriarchal power and women's images. In patriarchal power, she finds that women suffer from restrictions on mobility, having opinion, and career. In women's images, women are not expected to have career and inability for doing domestic work. In terms of responding it, she finds four struggles; working outside the house, expressing opinions, showing self-independence, and showing ability to work. After finding the problems and struggles of Grey, she concludes that women have the same ability to have a career like men get.

The researcher chooses Dan Brown's The Da Vinci Code novel as the material object. The Da Vinci Code is a 2003 mystery thriller novel by Dan Brown novel by an American author, Dan Brown and the fourth book in his Robert Langdon series, following Angels \& Demons, Inferno and The Lost Symbol. This novel was released on April, 2003 by Doubleday.

The Da Vinci Code provoked a popular interest in speculation concerning the Holy Grail legend and Mary Magdalene's role in the history of Christianity. The book has, however, been extensively denounced by many Christian denominations as an attack on the Roman Catholic Church, and consistently criticized for its historical and scientific inaccuracies. The novel nonetheless became a worldwide bestseller that sold 80 million copies as of 2009 and has been translated into 44 languages. This novel presents a woman who is the key of how the plot inside the novel moves. This become the reasons why the researcher chooses Dan Brown's 
The Da Vinci Code novel as the material object.

The researcher pays more attention to the role of Sophie Neveu as the main discussion in this research. The researcher is curious about Sophie Neveu's role as a woman character in the novel. It is an interesting topic because in this novel Sophie Neveu is presented as a genius woman character who often guides the main male character. She is a cryptologist. It means she gets equal right and opportunity to experience equal education as men so that she is considered as a reflection of women equality. Yet, she is alienated by her society work because of the fact that she is just a woman.

Based on the great issues of feminism above, the writer chooses liberal feminism theory by Betty Friedan to analyze The Da Vinci Code, especially to analyze the main female characters in the novel, Sophie Neveu.

The form used in this study is qualitative and uses descriptive methods, because in the research carried out only describes the description of what will be analyzed. Researchers use qualitative research because this study focuses on analysis or written material in context. Materials can include textbooks, newspapers, magazines, papers, films, manuscripts, articles, and so on. Qualitative method as a research procedure that produces descriptive data in the form of written or oral words from people and observable behavior. The analysis carried out by the researcher is by understanding the words written in the novel and Sophie Neveu's behavior or actions related to the main topic of feminism, then described based on the theory of the experts to get final conclusions.

The technique used in this study was 'read-note'. In the sense that the researcher will take any sentence, word, phrase, clause that is considered in accordance with the aims and objectives of the literary work being analyzed. Overall the researchers sort data in the form of narration or dialogue between characters in The Da Vinci code novel that shows explicitly or implicitly that Sophie Neveu is a reflection of women's equality, then the data is recorded and analyzed to get final conclusions.

\section{Finding and Discussion}

The equality of women in the social environment has been fought by feminists, one of which is Betty Friedan. In her book entitled The Feminine Mistique and The Second Stage, Betty Friedan theorizes that women and men as humans must be allowed to show their feminine and masculine qualities. Women and men are expected to work together to get happiness as an equal (as quoted in Tong, 2009: 32-33). By allowing women and men to show their feminine and masculine qualities, that means quality, that means women and men are in an equal position in society. Women and men have the ability to have feminine and masculine qualities.

Davies said masculinity and femininity are not private property but the structural nature of our society, these two concepts are conditioned and emerge from social interaction (Wibowo, 2013: 159). Although masculine qualities can be shared by women and men, this categorization still shows women's inequality. That is because feminine quality is a characteristic that is considered to be owned by women, and people see this quality as a low value while the masculine quality (a characteristic considered owned by men) as high quality. The masculine characteristics according to Remiswal are strong, competitive, courageous, 
unyielding, confident, independent, more adventurous, aggressive, assertive, intelligent and generally acting as leaders.

1. Strong

In general strong can be interpreted as physical defense against an attack. Another meaning of strong resolution is being able to withstand physical or nonphysical / psychological attacks and not easily waver.

Obviously he was angry at the photo ... Collet could hardly deny the unlucky one who succeeded the young woman. She has to decode written by dead family members. However, Sophie's reaction did not make sense.

Women have a more emotional nature than men. But it turned out that Sophie's determination was able to control her emotional nature. In escaping Sauniere who was none other than Sophie's own grandfather who was calm and not emotional. Sophie's calm attitude shows that the woman is strong who is able to control emotions.

\section{Compeitive}

Competitiveness is something related to competition or competition. In this case competitive can be positioned as a seizure condition or competitive condition that occurs or is experienced by someone or a group of people in winning the competition. In a seminar, the Women's Education Center (CEW) of the University of Michigan revealed that men were far more competitive and struggled in the world of work. Men demand more facilities for the company and the request is often acquired by the company. Even though the competitive nature of men is not closed, women also have competition, one of which is shown by Sophie.

As a 32-year-old woman, Sophie is very stubborn. His enthusiasm for continuing to complete new British cryptology constantly troubled the French veteran cryptographers who continued above. And what argues most against Fache is a universal truth that cannot be denied, that is, in an office full of separate men, a beautiful woman always distracts them from the work at hand "(Page 65).

Sophie was able to compete with her seniors in the field of cryptography, even younger than others, but Sophie was able to compete with people who were better than her.

\section{Courage}

Sophie's reaction is unexpectedly. Fache thought Sophie would be afraid of the cracks, but on the contrary Sophie responded to this crack with a struggling attitude.

Sophie's soft face turned hard and leaned over. "Captain, remember what you have to do tonight here, I think you might be happy to know that Sauniere is playing with you. I will inform you that it is shown to the director of cryptography that no longer needs our help."

Looking for the article, Sophie turned and walked to the direction, she entered earlier.

Fache was stunned, staring at her disappearing in the darkness. Is she crazy? Sophie Neveu has just made another channel for the suicide profession. 
From the quote above, it is undeniable that Sophie did not need to be intimidated by Fache's argument at all, but Sophie was increasingly difficult to maintain the arguments she considered right at high risk. Sophie's courage gave a strong warning to Bezu Fache, who was none other than her boss, making Sophie impressed as a courage woman.

\section{Unyielding}

Learning about allusions is given to anyone who has no caring or no gratitude to others. One's hard-hearted nature can be caused by a deep disappointment that eliminates the feeling of compassion and caring that someone has. Sophie shows her hard-hearted nature based on the quote below.

Too embarrassed and confused to bear the efforts of his grandfather to explain, she moved and took all of her money, important a small flat with several friends. He swore he would not talk about what he had seen with other people. His grandfather tried to contact her, sending her cards and letters, begging Sophie to meet him so he could explain. How do you explain? Sophie has never answered except once for forbid her grandfather from calling it a public place. He was afraid that his grandfather's explanation would be more terrible than the incident itself.

After seeing his grandfather (Sauniere) perform a kind of sex ritual that was considered embarrassing, Sophie ran away from her house and severed ties with her grandfather. Sauniere tried to contact Sophie in various ways, but the disappointment felt made by Sophie hard. Sauniere tried to explain everything but Sophie had already resented Sauniere.

\section{Confidence}

Confidence is one of the most basic and interesting traits someone wants to see. The nature of confidence also shows that someone always thinks of positive things. Good self-confidence also shows that someone is confident in his abilities. For some men, women who are confident are independent women and women who have many relationships. The body language that Sophie showed gave the impression that she was very confident. Her confidence can be seen by everyone including Langdon. Someone who has confidence will not hesitate to introduce themselves first.

Langdon was surprised because the woman immediately walked towards him and extended her hand politely. "Monsieur Langdon, I am Agent Neveu from the DCPJ Cryptology Department." Her words twisted beautifully in his Anglo-Franco mixed accent. "Nice to meet you."

Sophie politely introduced herself to Langdon, her gesture and the way she talked made fascinated Langdon. In addition to having a beautiful face, Sophie's confidence grew because she felt confident in her abilities as a reliable cryptographer.

6. Independent

In the novel The Da Vinci Code the female character code reflects selfreliance when Sophie lives apart from her family. 
Too embarassed and confused to endure the efforts of his grandfather to give explanation, Sophie immediately moved and took all of her savings, rented a small flat with several friends. He swore no will talk about what he has seen with other people. His grandfather tried to contact him, sending him cards and letters letter, begging Sophie to meet her so she can explain.

How do you explain? Sophie never answered except once to prohibit his grandfather from calling or trying to meet him at public places

Although the departure was forced because she felt disappointed, Sophie really showed independence. During his own life away from family she was able to face all problems alone. Sophie proves that women are also able to live independently without always having to depend on family or other people.

7. Aggressive

Sophie leaned forward and kissed Langdon again,

now on ... Soft at first, but then ... When Sophie pulled away, her eyes filled with promise.

"Fine," Langdon finally said. "This is a date."

The aggressive actions shown by Sophie prove that women can also act aggressively even more aggressively than men. This is done by a woman when she feels comfortable and trusts the man.Women's aggressive actions are not due to mere sexuality encouragement, if men behave sexually aggressively because they have a higher testosterone hormone, women who act more sexually aggressively because they put their trust in the man.

\section{Adventurous}

Conducting dangerous and high-risk actions has been carried out by Sophie many times.

Turning to the window, Sophie stared through the alarm roll embedded in a large glass, forty feet down which made dizziness. Jumping from here would break Langdon's leg. It's the luckiest. Sophie made a decision, finally. Robert Langdon had to escape from the Louvre, like it or not.

Sophie had thought about jumping from a height, but she undoed it because she was worried that Langdon would get hurt. Finally he decided to run away in another way . Running away from police pursuit shows that Sophie had spontaneous and unplanned courage like that of adventurers.

\section{Assertive}

Assertiveness is reflected by firmness in speaking to maintain something we believe in. Sophie's assertiveness was reflected when she denied Taebing's words that her family had died from being killed, since Sophie believed that her family had died in a car accident.

"That's a car accident." Sophie stomped, feeling her childhood sadness reappear. "An accident!"

With a loud voice Sophie confirmed to Taebing repeatedly that her family had died in an accident. The gesture Sophie showed by stomping on her feet showed that she was truly convinced and believed that her family had died in a car accident. 


\section{Smart}

Based on the results of these studies do not rule out the possibility that women can also have the ability to think the same as men. The intelligence of the woman reflected in Sophie has emerged since she was little

At the age of twelve, Sophie could solve the puzzle Le Monde crossword without any help, and her grandfather graduated her to crosswords in English, mathematical puzzles, and substitution ciphers. Sophie ate it all. Finally Sophie turned her love into a profession by becoming a police code-breaking expert.

From the quote proves that Sophie's motoric abilities have emerged since she was little. During this motoric ability is always identical to men. The male and female brains are created the same so that both allow them to be able to develop each other's brain abilities. If all this time the community thought that women could not act smart like men then it was a big mistake, the proof was Sophie was able to act smart and do a genius way to tell Langdon without Bezu Fache's knowledge.

\section{Act as Leaders}

The fact is that women can also act as leaders by giving orders, which are reflected in Sophie's attitude which always gives direction to Langdon.

Angry, Langdon walked toward the place to throw the tool the tracker.

"No!"' Sophie grabbed Langdon's hand and stopped him.

"Leave it in your pocket. If you throw it away, they will know you have found the tool. The only reason why Fache left you alone is because he can monitor your whereabouts. If he thinks you already know what he is doing ... "Sophie did not finish her thoughts. She just took the metallic disc from Langdon's hand and put it again in his wool coat. "Let the tracking device stay with you. At least temporarily."

Sophie barred Langdon from removing the tracking device that Fache had accidentally tucked into the jacket worn by Langdon. An order made by Sophie to prevent Langdon from removing the tracker was intended to outwit Fache and his team, so they suspected that Langdon and Sophie were still unaware of the tracking. Sophie showed her attitude as a leader by giving Langdon correct direction.

\section{Conclusion}

After analyzing the data based on Liberal feminism theory, this research discovers that Sophie Neveu as a reflection of woman equality that show masculine qualities character in the novel plays eleven roles i.e. strong, competitive, courageous, unyielding, full of confidence, independent, more adventurous, aggressive, assertive, smart and generally acting as leaders.

Sophie Neveu's role also proves that she gets equal right and opportunity as men in personal and economy aspects. In personal aspect, Sophie gets equal right and opportunity as men in enjoying equal education. In economy aspect, Sophie gets equal right and opportunity as men in managing her financial affairs. This case shows how important education for women is in order to be equal with men. 
Consequently, it can be known that the factor that makes Sophie is able to play her eleven roles is her educational background.

\section{References}

Abram, M.H. 2009. A Glossary of Literary Terms: Ninth Edition. Boston: Wadsworth Cengange Learning

Brown, Dan. 2003. The Da Vinci Code. USA: Doubleday

Creswell, W. John. 2013. Penelitian Kualitatif dan Design Riset. Yogyakarta: Pustaka Pelajar.

Mahi M. Hikmat.2011. Metode Penelitian Dalam Perspektif Ilmu Komunikasi dan Sastra, Yogyakarta: Graha Ilmu.

Nurgiyantoro, Burhan. 2012. Teori Pengkajian Fiksi. Yogyakarta: Gadjah Mada University Press

Tong, Rosemarie. 2009. Feminist Thought: A More Comprehensive Introduction (Third Eddition). Colorado: Westviews Press

Tong, Rosemary, 2008. Feminist Thought: Pendekatan Komprehensif Terhadap Kajian Feminisme, terj. Aquarini Priyatna Prabasmoro. Yogyakarta: Jalasutra.

Wibowo, Agung. 2013. Pemaknaan Maskulinitas (Kajian Sosiologis Tentang Pemaknaan Maskulititas Laki-Laki Di Kota Surakarta. Yogyakarta. 